\begin{tabular}{|c|c|c|}
\hline Beitr. Ent. & Keltern & ISSN 0005-805X \\
\hline $\mathbf{5 8}(2008) 2$ & S. $223-226$ & 15.11 .2008 \\
\hline
\end{tabular}

\title{
A new species of Chiasmognathus from Iran, with a note on Chiasmognathus aegyptiacus in Israel
}

\section{(Hymenoptera: Apidae)}

With 3 figures

\author{
Michael S. Engel
}

\begin{abstract}
Summary
A new species of the rare cleptoparasitic bee genus Chiasmognathus Engel (Ammobatini) is described and figured from a female collected in northwestern Iran. Chiasmognathus rhagae sp. $\mathbf{n}$. is generally similar to C. orientanus (Warncke) (Bulgaria, Turkey, Cyprus, Crete, and the Levant) or C. pashupati Engel (from southeastern Pakistan) but can be readily recognized by coloration and integumental sculpturing. In addition, a new locality in Israel is provided for C. aegyptiacus (WARNCKE).
\end{abstract}

\section{Zusammenfassung}

Für die seltene kleptoparasitische Bienengattung Chiasmognathus Engel (Ammobatini) wird eine neue Art anhand eines Weibchens beschrieben, das im nordwestlichen Iran gefangen wurde. Chiasmognathus rhagae sp. n. ähnelt allgemein C. orientanus (WARNCKE) (bekannt von Bulgarien, Türkei, Zypern, Kreta und Levante) und C. pashupati Engel aus dem südöstlichen Pakistan, kann aber durch die Färbung und Integumentskulptur leicht erkannt werden. Außerdem wird ein neuer Fund von C. aegyptiacus (WARNCKE) in Israel verzeichnet.

Key Words

Anthophila, Apoidea, Asia, Middle East, Levant, Iran, taxonomy.

\section{Introduction}

Bees of the genus Chiasmognathus are minute, rarely-seen cleptoparasites of the tribe Ammobatini (Engel, 2006, 2007). Species of the genus are exclusively known to victimize Nomioides spp. (Halictinae: Nomioidini) (ENGEL, 2006, 2007; Rozen, 2008) and more intensively collecting at Nomioides aggregations may eventually reveal a considerable unrecognized diversity in the genus. At present the genus is represented by relatively few specimens in collections and from a relatively limited number of localities ranging from northern Egypt through the Levant northward to Turkey, Bulgaria, Cyprus, and Crete; southward through Arabia; and eastward as far as Kyrgyzstan, Tajikistan, Pakistan, and Sri Lanka. Despite this sizeable range, considerable gaps exist owing to the limited collections of these Lilliputian bees.

Recently I received four specimens of Chiasmognathus from Dr. Laurence Packer, Toronto. Three females, collected in Israel, were of Chiasmognathus aegyptiacus (WARNCKE), a species well known in Egypt and Israel, albeit from very few documented localities. The fourth specimen, from northwestern Iran, was of a distinctive and undescribed species. This new species represents the first record of Chiasmognathus from Iran, although given the known locality records the genus 
was certainly suspected to occur there. Herein I provide an account of the new species as well as the new locality information for C. aegyptiacus in Israel. Morphological terminology follows that of Engel (2001) and Michener (2007), while the format for the description is generally based on those of ENGEL $(2006,2007)$.

\section{Systematics}

\section{Chiasmognathus rhagae sp. n. (Figs 1-3)}

\section{Diagnosis:}

The new species can be readily recognized by its smooth, polished, and impunctate mesoscutum (Fig. 2); castaneous head and mesoscutum (Figs 1-2); yellow clypeus and supraclypeal area (Fig. 3); yellow mesosomal pleura and legs (Fig. 1); and orange-yellow metasomal terga (Figs 1-2).

\section{Description:}

+. Total body length $2.81 \mathrm{~mm}$; forewing length $1.79 \mathrm{~mm}$. Head wider than long (width $0.79 \mathrm{~mm}$, length $0.63 \mathrm{~mm}$ ); inner margins of compound eyes straight, convergent below; apex of clypeus at lower tangent of compound eyes; ocelli above upper tangent of compound eyes (Fig. 3); clypeus weakly convex, nearly flat; malar space vestigial; mandibles simple, crossing in repose but not covering labrum. Intertegular distance $0.42 \mathrm{~mm}$. Forewing marginal cell broadly truncate (Fig. 1); both m-cu veins entering second submarginal cell.

Head with small, well-defined punctures separated by 1-3 times a puncture width, integument between punctures smooth and shining. Mesoscutum impunctate, smooth, and shining (Fig. 2); tegula impunctate, translucent; mesoscutellum smooth and shining, with a few small punctures; pleura with small, well-defined punctures separated by $0.5-2$ times a puncture width, integument between punctures smooth and shining; posterior and lateral surfaces of propodeum faintly imbricate, impunctate. Metasomal terga faintly imbricate, with a few minute punctures; sterna faintly imbricate and impunctate.

Integument generally yellow (Figs 1-2) except red on mandibular apex; castaneous on gena, face above clypeus and supraclypeus (Fig. 3), vertex, mesoscutum (Fig. 2); mesoscutellum and metasomal terga orange-yellow (Fig. 2). Wing veins yellow, membranes hyaline.

Pubescence white (Figs 1-3). Head with numerous, fine, subappressed, suberect, or erect plumose setae (Fig. 2), such setae intermingled with a few suberect to erect finer, simpler setae. Setae of mesosoma like those of head although more sparse centrally on mesoscutum (Fig. 2) and medioanteriorly on mesoscutellum, somewhat obscuring pleura, metanotum and portions of propodeum. Metasoma with scattered, erect to suberect simple setae, with thin and weak apical fasciae composed of appressed, plumose, white pubescence on second through fifth metasomal terga; first metasomal tergum with small, weak apicolateral patches of appressed plumose setae; sterna with scattered subappressed to suberect, largely simple setae.

\section{Holotype:}

+ (Figs 1-3); IRAN: Tehran, 18 Delavix St., in pool, 4-6.viii.1977 [4-6 August 1977], John T. Huber; deposited in the Bee Collection, York University, Toronoto, Canada.

\section{Etymology:}

The specific epithet is the classical name for what is known today as the ruins of Rayy in Iran. 


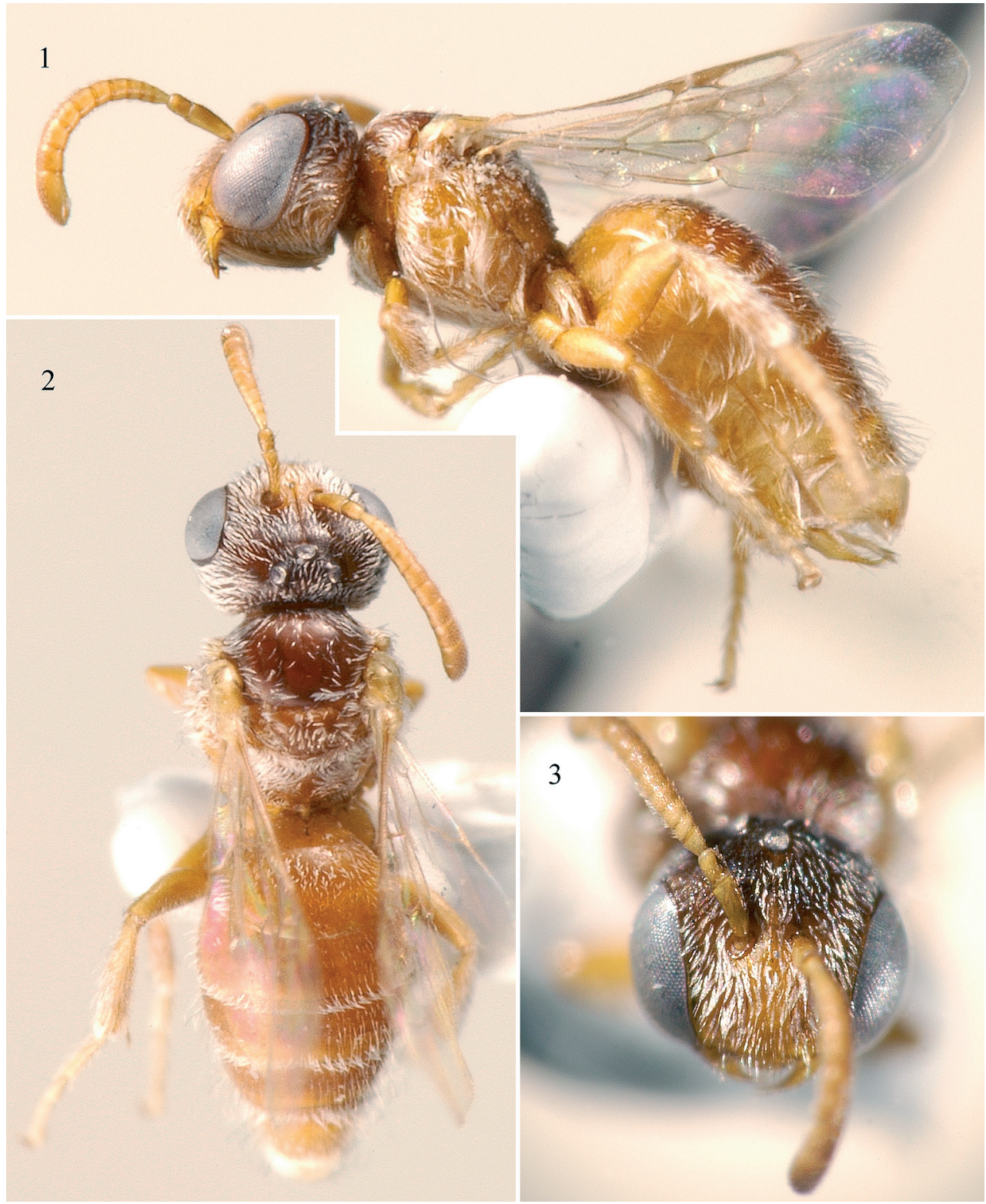

Figs 1-3: Photomicrographs of holotype female of Chiasmognathus rhagae nov. sp. (1) lateral aspect; (2) dorsal aspect; (3) facial view.

Rayy lies inside of the greater metropolitan area of Tehran and was built by the Median Empire approximately 5000 years ago. The Greeks called the area comprising modern Kurdistan, Azerbaijan, and northwestern Iran (roughly Esfahan, Hamedan, Tehran, Zanjan, and neighboring provinces around the Zagros Mountains, although the ancient Median Empire at times extended further south in modern Iran and as far east as Kashmir) "Medea" or "Media" [the Latin adjective of which is median ("in the middle"), and for which Osmia mediana ENGEL from nearby Karaj was named], and the people of the region, the Medes. 


\section{Comments:}

The new species is most similar to C. pashupati ENGEL from southeastern Pakistan. Both have a similar castaneous coloration overall, although somewhat more light in C. rhagae. Chiasmognathus rhagae also has the clypeus and supraclypeal area noticeably yellow in comparison to the otherwise castaneous head (Fig. 3). More significantly, however, while C. pashupati and other described species of Chiasmognathus have some degree of mesoscutal punctation and sculpturing, C. rhagae has a smooth, polished, and impunctate mesoscutum (Fig. 2). In this last feature, C. rhagae is similar to an undescribed species from Yemen but differs in the fact that the latter is dark brown to black among other traits.

\section{Chiasmognathus aegyptiacus (WARNCKE)}

New record: 3 우 우, ISRAEL: Negev, Sapir gas station, 15.v.98 [15 May 1998], L. Packer, at Nomioides sp. nests; specimens in the Bee Collection, York University, Toronoto, Canada.

\section{Comments:}

This is a new locality record within Israel for this species which was hitherto only recorded in this country from near Jericho (WARNCKE 1983).

\section{Acknowledgements}

I am grateful to L. PACKer for bringing this material to my attention and permitting me to study it. This is a contribution of the Division of Entomology, University of Kansas Natural History Museum.

\section{References}

EngeL, M. S. 2001: A monograph of the Baltic amber bees and evolution of the Apoidea (Hymenoptera). - Bulletin of the American Museum of Natural History 259: 1-192.

ENGEL, M. S. 2006: A new genus of minute ammobatine bees (Hymenoptera: Apidae). - Acta Entomologica Slovenica 14 (2): 113-121.

Engel, M. S. 2007: A new species of Chiasmognathus from southeastern Pakistan (Hymenoptera: Apidae). - Journal of the Kansas Entomological Society 80 (2): 169-174.

Michener, C. D. 2007: The Bees of the World [2nd Edition]. - Pp. xiv + [i] + 952, 20 pls. - Baltimore: John Hopkins University Press.

Rozen, J. G. JR. 2008: Biology and immature stages of the bee Nomioides patruelis (Halictidae: Halictinae: Nomioidini) and of its cleptoparasite, Chiasmognathus pashupati (Apidae: Nomadinae: Ammobatini), with a preliminary phylogeny of the Halictidae based on mature larvae (Apoidea). - American Museum Novitates 3604: 1-23.

WARnCKe, K. 1983: Zur Kenntnis der Bienengattung Pasites Jurine, 1807, in der Westpaläarktis (Hymenoptera, Apidae, Nomadinae). - Entomofauna 4 (21): 261-347.

\section{Author's address:}

Prof. Dr. Michael S. ENGEL

Division of Entomology (Paleoentomology)

Natural History Museum

1501 Crestline Drive - Suite 140

University of Kansas

Lawrence, Kansas 66049-2811, United States
Subject editor:

Prof. Dr. H. H. Dathe 